\title{
WILEY

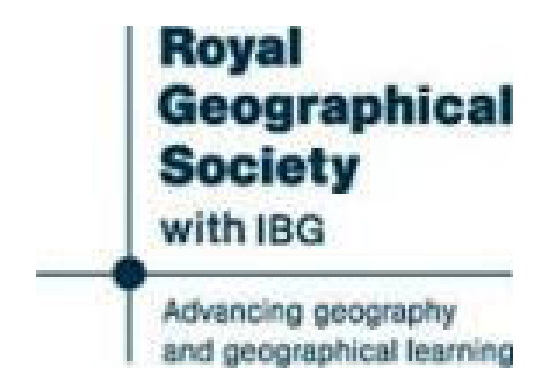

Notes of a Visit, in May 1875, to the Old Calabar and Qua Rivers, the Ekoi Country, and the Qua Rapids

Author(s): James Broom Walker

Source: Proceedings of the Royal Geographical Society of London, Vol. 20, No. 3 (1875 - 1876), pp. 224-230

Published by: Wiley on behalf of The Royal Geographical Society (with the Institute of British

Geographers)

Stable URL: http://www.jstor.org/stable/1799766

Accessed: 15/06/2014 02:04

Your use of the JSTOR archive indicates your acceptance of the Terms \& Conditions of Use, available at

http://www.jstor.org/page/info/about/policies/terms.jsp

JSTOR is a not-for-profit service that helps scholars, researchers, and students discover, use, and build upon a wide range of content in a trusted digital archive. We use information technology and tools to increase productivity and facilitate new forms of scholarship. For more information about JSTOR, please contact support@jstor.org. 
he adds, that "he will describe the six that he actually visited, omitting the other two, which he had no opportunity of seeing." The positions of these six, then, I think I have now unquestionably settled.*

\section{2.-Notes of a Visit, in May 1875, to the Old Calabar and Qua Rivers, the Ekoi Country, and the Qua Rapids. By Captain JaMES Broom W ALKER, F.R.G.S.}

\section{Visit to the Old Calabar River.}

On the morning of Monday, March 8th, 1875, started on a trip up the Calabar River, calling at the villages of Ikot-Mbä and Adiabo, where there are Mission Stations supplied by native agents from Creek Town, and after visiting the first Ingpara hamlet, we came to Upper Ingpara, where we spent the night. The headman of the village received us very courteously, and gave us lodgings. This is the last Calabar town up this river, but a good many Creek Town people have farms along the banks of the river as far up as Uwet.

Pursuing our course next morning, we passed a village of the Aukanyong people, which we visited on our return and found pleasantly situated. This is a tribe originally from Aurandöp, and inhabits a narrow strip of land running across the peninsula between this and the Cross River. A little palm-oil is made, but the people occupy themselves chiefly in raising food. The want of confidence between them and Calabar, resulting from a war several years ago, has till now shut against them their principal market.

Farther up, we passed the Odüt Creek, a small inlet which goes into a district of that name. Another creek entering from the Cross River a little above Ikünetï is almost conjoined with it in the rainy season. The people of Odüt are a mere handful of emigrants from Ibibio. Here on both sides of the river for a considerable distance lie the farms of the Creek Town people, occupying land formerly belonging to Uwet, purchased by King Eyo II. in following his policy of planting his people here and there throughout the country on the banks of the river, so as to spread his power. 'The elephant is found in this district. The natives never venture to attack him, but when numbers come out of their haunt to plunder the farms, the people drive them off by fire and noise.

At a farm bamlet called Aqua Efe we rested, and prepared dinner. Again taking the boat, we pursued our way, the river being now a narrow stream and the channel much intercepted by trees and sand-banks. About dusk we reached Uwet, and took up our quarters in the Mission Station recently formed here.

The people of this quarter are originally from Akuna Kuna on the Cross River. From that an attempt was made in former years to get a direct trade with the European ships frequenting the Calabar River; but the people of Umon, who have planted their town on an island in the middle of the river, so

* Mr. Thomson, as he mentions, has not seen my edition of 'Marco Polo,' nor, apparently, a paper on the subject of these kingdoms by the late Mr. J. R. Logan, in his 'Journal of the Indian Archipelago,' to which reference is made in the notes to 'Marco Polo.' In the said paper and notes the quotations and conclusions of Mr. Thomson have been anticipated; and Fansúr also, which he leaves undetermined, identified.- $[$ H. YuLE. $]$ 
as completely to command it between Akuna Kuna and Calabar, blocked up the way. This led some of the people of Akuna Kuna to pass over towards the other river, and a number of these found a settlement at Uwet, inhabiting three villages called Uwet, Ikpit, and Ewen. These were formerly much larger than we now find them; but their heathen customs of blood, especially the frequent use of the poison ordeal, are wiping them off the face of the earth. We trust that the Gospel now taught them by the native agents from Creek Town, who occupy this station, may be in time to save them. After taking observations next day, we took boat to the rapids, which close even canoe navigation. They lie a short distance from the town. The river flows between steep banks of considerable height covered with forest, said to be the haunt of the chimpanzee, its channel filled with rocks and boulders, and at one place there is a fall of about 6 feet. Those going into the interior towns, leave the river here and strike off up the face of the steep bank on the right bank.

Farther up amongst the hills three small streams unite to form the river. The hippopotamus is not found in it as in the Cross River, but the crocodile abounds in both.

\section{Visit to the QuA River.}

Monday, March 22nd, 1875.-This morning set out on a voyage up the Great Qua River, which enters the Cross River below James Island. Our first day's travel was up the wide river, bordered by the usual low swampy ground covered with mangrove forests. Of the mangrove, which is so great a boon to these rivers, by drinking up the miasma of the swamps, the Calabar people name three varieties. The rarer species, not common on the upper courses of the river, we found here. In the evening we made Qua Landing, which is but a few miles behind Duke Town, overland, and took up our quarters for the night. The village here belongs to the Qua people; but, as it is a port for the Duke Town people in going to and coming from their farms in Akpabioyo, a number of Calabar people are always found about it. The headman declined to receive us for the night, never having accommodated white guests, and having no place in his house which he thought would suit. In our dilemma, a young man, who had formerly been to school at Old Town, got accommodation for us in the yard of a pleasant-looking old man, with whom he seemed to be connected.

Resuming our course in the morning, we passed by the landing for the Cape Town farm, which lies several miles off the bank of the river in a hilly region, and which time did not permit us to visit. Proceeding, we rested for our mid-day meal, and the flow of the flood-tide, at a small farm belonging to an Old Town man, who gave us his name as Kofi Robert. His principal farm was about a mile over a hill, and hearing of the arrival of white men he came down to see and invite us up to his house. We accompanied him thither, and on returning recommenced our progress up the river.

We passed on our way various farm beaches, and after a weary pull, about dusk reached an Old Town hamlet, the farthest up the river. A bank of shale here projects itself into the river, having the appearance of a wharf and serving the purpose of one. On our arrival we sent up to the village to announce our presence, and the headman, Efium Cobham, came down to meet us, but was evidently afraid to receive us, saying: "We are slaves of the white man, there is the village, go take it." He no doubt suspected that he might be called in question by the Calabar authorities for giving us accommodation, they being not at all desirous that strangers should penetrate the country. At length we got into a house, and established ourselves for the night, our every movement, as usual, being closely watched by the people, whose curiosity was greatly excited by the unwonted visit of a white man. 
We set off in the morning to get up to the rapids, if possible. The people assured us we should not be able to proceed so far in a boat, and we, after rowing two or three hours in a channel rendered intricate by trees and sandbanks, found this to be the case. About noon we were obliged to retrace our way to the village we left in the morning, the rapids still several miles beyond the farthest point reached, though quite accessible in a canoe.

The Qua River descends from the range, proceeding interiorly from the Cameroons, part of the range sometimes getting the name of Rumby.

Possibly the Cross and the Cameroon rivers may have their source in the same range. The region through which the Qua flows, including that now occupied by the Calabar people of Old and Duke Town, was, and for the most, part still is, in the possession of the Qua or Aqua people. They are of the Ekoi tribe, which inhabits a wide region traversed by the mountain range, going over probably as far as the country watered by the Cameroons. This. tribe in past times traded with Calabar in slaves, but now farm-produce and a small quantity of ebony are the articles of their traffic.

\section{Visit то EkoI.}

Thursday, April 15th, 1875.-Proceeded from the Hulk Dawstone at 1 P.M. to Adiabo ; arrived at the above place at 4 P.M., and remained all night at the United Presbyterian Mission House of the station here.

Friday, 16th.-At 8.50 A.M. started for the Ekoi Creek above Small Inkpara; on the left bank, at 4.30 P.M., arrived at Aukanyöng, landing. at the head of canoe navigation, after a long and tedious pull through a very intricate channel. Found at the landing a shed erected in charge of an Aukanyöng man, who kindly offered to take charge of the boat, \&c., until our return. I gladly accepted his offer, and at 5 P.M. started part of the caravan. for Auköyöng Village, distant in a north-east direction $1 \frac{3}{4}$ mile. At 7 P.M. I started with the rear of the caravan, and arrived at the above village at 8 P.M. Found the chief of the village had prepared dinner. The village stands on a hill, and is beautifully situated. The road from the landing to this place is up a hill and very rocky. Passed a stream, running east and west, about a mile from the landing, which I found to be a continuation of the Ekoi Creek. This village is inhabited by a portion of the Aukanyöng tribe, who seem to have the gift of spying out the best land for farming. The chief produce of this district consists of yams, plantains, Indian corn, and palm wine. Useng is the name of the chief of the place; and I must state here he treated us with marked kindness, and supplied us with carriers to the next village.

Saturday, 17th.-At 9.50, after taking observations for longitude, started for Okïno Village in a E.N.E. direction, passing down bill. Found the road very rocky, and at 10.15 came to a cataract, which runs into the Ekoi Creek below the Aukanyöng Landing. Halted for twenty minutes to bathe; started. at 10.35 for Okio Village through a dense forest up and down hill, with stones and rocks abounding. The forest trees prevented the rays of the sun reaching us, which made the travelling very pleasant. At 11.25 arrived at the above village and engaged new carriers.

'I'he chief of the village being at his farm, we left a small present and made a short halt. This village is also very pleasantly situated on the summit of a hill on a clear patch of ground. The people who inhabit this town are part Efik and part of the Ekir tribe. Their chief occupation is raising food-yams, plantains, and Indian corn; india-rubber is found here, but it is only used as bird-lime.

At 11.40 started in a north-west direction down hill, through a dense forest, with stones, rocks, and streams abounding. After passing eight streams, we 
ascended a hill and reached Asuquay, a Calabar village, situated in a clear patch of land, the farms lying in all directions round the village. This village is inhabited by the Ekoi tribe principally, and their chief occupation is raising yams, plantains, Indian corn, and live-stock-goats and fowls. The chief of this village is dead. On our journey in a north-east direction passed a yamand corn-field; stones and rocks abound, but the farmers plant all around, and leave them where nature has placed them. Passed on through a jungle for a mile, which was less pleasant than the forest, the rays of the sun scorching us and making the walking very unpleasant. At 1.55 arrived at Krüt Enim, or the Elephant's Head, a clear patch of ground in the dense forest, where the inhabitants of Mbareikom Town killed an elephant, hence its name. At 1.56 proceeded in a north-east direction down hill, and at 2. P.M. reached a stream. Halted, and bathed here, and at 2.20 started for Mbareikom Town, situated in the centre of the Ekoi country. At 2.30 arrived at the above-named town, and were received by the people with great joy, at seeing white men visiting their country in company with the Rev. Esien E. Ukpabio, their future teacher and pastor. This town is situated on a hill, and will be the chief town in the country. The people here raise food-yams, plantains, and cornand supply the neighbouring tribes, Calabar, \&c. The chief products of this country are ebony, india-rubber, and kola-nuts, and a nut which makes a butter somewhat similar to the Shea butter. The United Presbyterian Mission has placed a station here, which was much needed. The whole of the country lying east and west from the banks of the Great Qua and the Uwet rivers, bounded on the north by the Uyanga tribe, and on the south by the Calabar people, has not had any communication with Europeans direct, nor have they been visited until very lately. This country is teeming with population, and ripe for a Mission Station. This will in some future day be the basis of a line of stations far into the interior, reaching the banks of the Chadda River, and striking direct across the continent to the Red Sea.

Sunday, 18th.-At 9.7 P.M. we observed the meridian altitude of the star Dubho, to determine the latitude and to enable us to start at noon the following day.

Monday, 19th.-At 7 A.M. walked a short distance in a northerly direction to see a large tree which produces a nut that makes a butter like the Shea butter. The tree was not bearing, but found a specimen of the nut lying on the ground. This is the only tree of the kind in the district. The tree producing the kola-nut grows extensively, and might be made an article of future trade. Returned, after passing through a village near Moarekono. Took observations of the sun for longitude at 9 A.M. At 11 A.M., after being shown great attention by our host, whose name is Itaökpo, we started for Aukanyöng village, and reached there at 9.35 P.M., when our kind host prepared dinner for us, and we rested for the night.

Tuesday, 20th.-Started for Aukanyöng Landing and embarked for Adiabo; reached there at 4 P.M., and rested for the night.

Wednesday, 21st.-After breakfast started for Creek Town, and arrived there at 1 P.M. Proceeded to the Dawstone; arrived at 2 P.M.; making the journey in 7 days.

\section{Visit to the Qua Rapids.}

Monday, May 3rd,1875.-Started at 5 A.M. for the rapids of the Great Qua River. Proceeded towards Creek Otip, 1 mile below Henshaw Town, and entered the mouth of the Creek at 6 A.M., and passed out into the Qua River at 8.10 A.M. Proceeded on our journey, and at 10.40 A.M. anchored below the Duke Town Landing to breakfast. At 11.20 proceeded on our course, and arrived at Archibong Willy's of Old Town farm-beach Landing. At 2 P.M.,

VOL. $\mathrm{XX}$. 
1 mile above Kofi Robert Landing. At 3.30 started for Archibong Willy's plantation, up hill, in a south-easterly direction, and passed Kofi Robert and John Anderson's farms, lying to the right. Changed our course to east by south, going down hill. At 4.10 passed Hogan Archibong's plantation. Bearing south by east, at 4.20 came to Archibong Willy's head slave's farm on a hill ; halted for 10 minutes. At 4.30 proceeded down hill in a north-east direction, and at 4.35 passed a large yam- and corn-field to the right and left; and at 4.40 passed Effiong George's plantation to the right, going up and down hill. At 4.50 arrived at Archibong's plantation, of which I estimate the distance from the landing to be 4 miles. The whole of the road from the landing to the plantation is shaded with tall forest-trees, except when you approach the farm, where the ground is extensively cultivated for a mile in extent round each farm. The soil is very rich and productive, and well watered with streams. The chief products of the district are yams, Indian-corn, and plantains. At 5.30 Archibong and his farm people, hearing of our arrival at his house, walked in to welcome us, which he did in a most cordial manner.

May 4th.-At daylight, after coffee, our host invited us to look at his yamand corn-fields, which lay in an E.s.E. direction from his house, up hill, for 2 miles in extent, all cleared ground and under cultivation. Estimated the people at this farm to be no less than 100 persons-men, women, and children. Taking on an average 50 persons at each of the other four plantations which we passed, and at one 2 miles further in the interior, making a total of 350 persons at work on these farms.

At 12.30 obtained a guide from Archibong, and permission to occupy his farm-house situated immediately above the rapids, on the right bank of the river. Took farewell of our kind host, and proceeded for the landing. At 1.50 arrived at the landing. At 3.35 started on our journey with the floodtide. At 4.50, pursuing our course, passed some patches of elephant-grass and wait-a-bit thorns on the left bank; and on the right bank passed several fine bombax-trees. At 6.15 arrived at Obutong, our old quarters, and after dining, rested here for the night. Cobham Effiong was the headman of this town, but he has been dead for some time, and now his head slave occupies the town. We found him suffering from a sore leg. $\mathrm{He}$ was unable to move about, however, with our guide, who is a free young man; he made us very comfortable.

5 th.-At 6 A.M. proceeded on our journey for the rapids. 11.35 anchored for dinner abreast of an Ekoi landing. We saw here several Calabar canoes taking in ebony on the left bank. Found the river much higher than when last here, the sand-banks being completely covered, giving the river a wider and more beautiful appearance. Passed two islands, to the first of which I gave the name of Grant, and the second I called Bates Island. 12.35, proceeded on our course. At 1 P.M., on nearing the right bank-head, heard a rushing of water and roaring, but could see nothing. Stopped pulling, and hauled the boat close into the bank, and found a small creek, with a fallen tree lying directly across the mouth, stopping ingress and egress. The roaring of the water became more distinct, so determined to ascertain what it was. The bow-oarsman was ordered to clear the brushwood, and I landed and walked about 40 yards in a direct line from the beach, and bebeld a cataract with a fall of 100 feet, the water falling over the immense cliffs, and rushing down the rocks with great rapidity into a basin beneath. I stood for a few minutes and sketched the fall, which was magnificent in the extreme, the trees shading the water on both sides making the scene a truly picturesque one. The cataract is about 2 miles below the rapids on the right bank. After picking up a few specimens of stones from the sides of the basin, we proceeded, and at 2.15 arrived at the lower rapids, the width of which we 
determined to be 100 yards, with a fall of 20 feet. Landed at Archibong's beach, and was received by the inhabitants with shouts of joy. Walked along the right bank, which is within 200 yards of Archibong's farmhouse, situated an a hill immediately above the rapids, and beheld another fall of 50 feet. The rushing of the water was exceedingly grand, the land rising almost perpendicularly on both sides, forming an immense gorge, which bears the mark of a great rise of the river during the rains, with the primeval forest-trees overhanging the banks of the river, causing a shade, and, together with the mist and roaring of the water, making the surrounding scene one of surpassing grandeur.

The height of the banks I estimated at 300 feet above the rapids on both sides. Walked up the steep cliffs in a north-west direction, and reached Archibong's farmhouse, a distance of half a mile from the landing, close to the lower rapids. It struck me at once that this would be the place for a sanatorium for the Old Calabar Mission, and if Mr. George Thomson had selected this spot for his site, instead of going to Cameroons, he would have been wise.

6th.-At 6 A.M. King Abasi of Oruk, of the Ekoi people, with fifteen followers, arrived at our lodging from the opposite bank, where his town Obutong Ekoi is situated, to welcome us to his country, and offer his services as a guide to visit the upper rapids on the opposite bank. Proceeded with him across the river opposite Archibong's Landing, and climbed this steep cliff of 300 feet, and then proceeded on level ground for 2 miles in an E.N.E. direction, until we came to a yam- and corn-field, when we altered our course to due north, and, after walking a mile, struck the cliffs immediately over the higher rapids. Descended the cliffs in a slanting direction, holding on to the roots of trees, until we found ourselves at the bottom of the greatest fall of the higher rapids, the fall which the King declared to be the highest. I estimated it at 100 feet. Walking over the immense boulders until we saw the fall right before us, we sat down to witness the surrounding scenery, which was too grand a sight for my pen to describe. Picked up a few stones and commenced our return, when we found it absolutely necessary to take off our boots for fear of tumbling into the gulf of water immediately below us. 'The foam, and mist, and roaring were confusing, and the slippery nature of the boulders made it difficult for us to move about. On our return we passed a number of villages, his Majesty remarking that he was "King for them all." $\mathrm{He}$ insisted that I must visit his town, which I did, and was received with shouts of joy by his people. He remarked that it was difficult to keep goats, on account of the leopards prowling about night and day, and carrying them off. The people of the district raise yams and plantains for their own consumption only. Their chief occupation is acting as brokers between the Calabar people and the hill-people, the latter preparing the ebony for exportation. Found a Calabar man here buying ebony from King Abasi Oruk, who buys it direct from the hill-people. And so the trade is carried on from one to the other, each making profit sufficient to provide for his wants, which are few indeed. The town is built like Calabar towns, of mud walls, and roofed with bamboo-mats. Started for the Ekoi Landing, and crossing the river, arrived at Archibong's Landing at 11 A.M. Three Ekoi people came, sent as a deputation from their King to invite us to visit his town, and another, and much larger fall, at some distance from this place, which I supposed they must have meant the fall of the Cross River, which bears north-east by east, distant about 30 miles, according to the position Captain Beecroft marked the rapids on his chart, but declined at present. With some aid from the Society, I would be glad to give the position of the higher rapids of the Cross River, if it was thought of any moment to know the exact position.

At noon started on our home-journey. At 4 P.M. arrived at Obutong village, 
occupied by Old Town people, took in some boxes, \&c., which had been left behind to lighten the boat, and then proceeded. Arrived at Archibong's Landing, 1 mile above Kofi Robert's; landed and walked out to his farm to pass the night.

7th.-At noon started to visit all the old Town farms on the road. The day being clear and fine, saw a range of hills from Kofi Robert's farm; sketched the range, and proceeded. Left the landing at 2 P.M., and arrived at Okom at 5 P.M., where I took up my old quarters and rested for the night.

8th. - Started at 6 A.M., and proceeded through Olip Creek, and arrived at the Dawstone at 2 P.M., making the voyage in six days.

\section{On the Discovery of a Boiling Lake in Dominica. By H. Prestoe, Botanist, Trinidad.}

\section{[Communicated by the Coloniar Office.]}

The Surveyor-General, Dr. Nichols, and myself, started in the morning from Roseau, and reached the first souffriere in the Souffriere Valley the same evening. Here we constructed "adjupos" for the night, the Boiling Lake being nearly two hours" walk further on, and which we reached the next day about one, having examined the several souffrieres of the valley en route.

Our route lay viâ the district at the head of the Roseau Valley known as "Landats," and across the southern portion of the Coliabone range of hills, and the three or four branches of the "Mirale" River, south-eastward; thence up the most southern of the branches of the River "Mirale " a little southward; and finally up its south-east branch to the head of the Souffriere Valley; thence down the Souffriere Valley and up a minor valley north-westward to the Boiling Lake.

One of the ridges in the Coliabone range was traversed at an elevation of 2475 feet by aneroid, but the route presented no particular difficulties until the upper part of the most southern branch of the Mirale River was reached, and here, on account of the precipitous hills on both sides of the watercourse, much obstructed by huge toulders, this had to be followed to the bead of the Souffriere Valley, elevation 2680 feet.

At this point the passage became excessively difficult and dangerous from the precipitous character of the hill-side, down which it was only possible to proceed by clinging to the tree-stems. Reaching the watercourse of this valley the route continued down it, and again up that of the minor valley leading north-westward to the Boiling Lake; the difficulties of the last portion of the route being increased by the large volume of very hot water coursing down from the innumerable "Souffirere" issues higher up.

The nature of the Boiling Lake is, I believe, exactly the same as that of the many "Souffrieres" in the adjoining valley, and those I have seen at the head of the Roseau Valley. It differs from them only in size and position. Thesesmaller souffrieres are all aqueous solfataras, with, apparently, an excess of ejective power (exerted by their gases and heat) over the water which effects them, and which drains from the adjacent hills. The Boiling Lake is a giganticsolfatara, with, apparently, an excess of water over the ejective power exerted by its gases and heat. In its case the water affecting it flows in from two converging ravines, which meet on its north-west corner in very considerable volume.

The action of the solfatara, together with the existence of a small hill immediately opposite the point of ingress of the water, have caused the formation of a crater-like cavity with precipitous sides, on the north-east and south- 